\title{
KEMUNCULAN TAHAP MENULIS ALFABET PADA GAMBAR EKSPRESIF ANAK USIA 5-6 TAHUN
}

\author{
Putri Megasari \\ e-mail: putri_megasari08@yahoo.com \\ PG-PAUD FIP Universitas Negeri Jakarta
}

\begin{abstract}
Abstrak: Penelitian ini bertujuan untuk mendeskripsikan kemunculan tahap menulis alfabet pada gambar ekspresif anak usia 5-6 tahun di Pos PAUD wilayah Kecamatan Kebayoran Lama, Jakarta Selatan. Penelitian yang dilakukan Oktober 2013 ini merupakan penelitian kuantitatif dengan teknik survei terhadap 75 anak yang diklasifikasikan dari usia 5 tahun 0 bulan sampai 6 tahun. Data dikumpulkan dengan dengan teknik wawancara terstruktur dan dinalisis menggunakan tehnik persentase. Temuan hasil penelitian menunjukkan, kemunculan tahap menulis alfabet anak pada tahap menulis huruf dan menulis nama sendiri muncul sejak anak usia 5 tahun 0 bulan. Menulis rangkaian huruf yang merepresentasikan sebuah kata, menulis berdasarkan fonem dan menulis kata, baru muncul di usia anak 5 tahun 1 bulan. Menulis kalimat pendek sesuai ejaan, muncul di usia anak 5 tahun 7 bulan sampai dengan usia 6 tahun, sedangkan menulis sendiri cerita sesuai dengan gambar yang dibuat muncul dari usia 5 tahun 10 bulan sampai dengan 6 tahun. Hasil penelitian ini memberikan implikasi kepada orang tua dan guru dalam mengenali kemampuan menulis anak.
\end{abstract}

Kata kunci: tahap menulis alfabet, gambar ekspresif, anak usia 5-6 tahun

\section{EMERGENCE OF ALPHABETIC WRITING STAGES IN EXPRESSIVE DRAWINGS OF THE CHILDREN AGED 5 -6 YEARS}

\begin{abstract}
This purpose of this study was to reveal the emergence of alphabetic writing stage of the expressive drawings of the children aged 5-6 years in Early Childhood Education Services Post in Kebayoran Lama, South Jakarta. The study, conducted October 2013, employed quantitative method using survei techniques. The participant of this research involved 75 children ranged from the ages of 5 years 0 month to 6 years. Data were collected by using structured interview guides and analyzed with percentage technique. The findings show that the emergence of alphabetic writing stage when the children are able to write letters and their own names appears at the age of 5 years 0 month. The emergence of writing integrated letters to form a word, phoneme writing, and word writing appears at the age of 5 years 1 month. The emergence writing short sentence appears as from the ages of 5 years 7 months to 6 years, while the emergence of writing story writing appears as from the ages of 5 years 10 months to 6 years. The findings have implication to the parents and teachers in identifying the development of the children's writing ability.
\end{abstract}

Keywords: alphabetic writing, expressive drawing, children aged 5-6 years

\section{PENDAHULUAN}

Kemampuan menulis anak prasekolah, muncul dimulai dengan ketertarikan anak pada kegiatan menulis yang berawal dari kegiatan mencoret-coret, mencoba menulis huruf dan angka, menulis namanya sendiri dan mampu menulis kata sesuai tulisan. Menulis memiliki tahapan-tahapan perkembangan yang mempunyai ciri dan peranannya masing-masing yang harus diperhatikan dan dipahami oleh orang dewasa. Hal ini, karena setiap anak akan mengalami proses tersebut dan melewatinya seiring dengan pertumbuhan dan perkembangan yang sejalan dengan pertambahan usia anak sendiri.

Anak usia prasekolah, pada umumnya sedang memasuki atau berada pada tahap menulis alfabet (alphabetic writing). Tahap menulis alfabet (alphabetic writing) merupakan salah satu bagian dari tahapan perkembangan menulis anak setelah serangkaian tahap pre-alphabetic writing yang dialami dan dilewatinya sekitar usia satu sampai tiga tahun. Dalam perkembangan menulis pada tahap menulis alfabet (alphabetic writing), tulisan yang dibuat anak sudah dapat diidentifikasi dan terbaca. Anak mulai menulis 
berupa coretan atau gambar yang membentuk rentetan huruf-huruf, menulis nama sendiri, dan menulis kata. Dengan begitu, coretan yang dibuat anak bukan lagi hanya berupa simbol gambar yang menggambarkan imajinasinya tetapi sudah munculnya bentuk simbolsimbol berupa tulisan. Hal ini sebagaimana dalam Jalongo (2007:252) tahap alphabetic writing dalam perkembangan menulis anak, pada tahap ini tulisannya menjadi lebih mudah dibaca. Anak mulai menulis huruf-huruf maupun angka serta kata, namun penempatannya masih secara acak dan sembarang.

Anak menulis menggunakan pena atau pensil di atas berbagai media yang menghasilkan huruf atau angka serta gambar sebagai ekspresi dari perasaan dan pikiran anak sendiri. Salah satu media tresebut adalah gambar yang merupakan hasil dari visualisasi pengungkapan perasaan dan pikiran serta pengalaman yang dituangkan dalam media kertas. Hasil karya seni gambar yang dibuat anak dari aktivitas menggambar mampu memberikan informasi akan pesan, maksud dan tujuan yang ingin disampaikan oleh anak. Hal ini terlihat dari coretan, bentuk gambar yang dihasilkan, hubungan antar objek gambar, serta warna-warna yang digunakan. Dengan begitu, anak merasa senang ketika gambarnya ditanggapi oleh orang dewasa yang ada disekitarnya yaitu orang tua dan guru dengan pertanyaan tentang makna dan arti bentuk gambar atau tulisan yang dibuatnya.

Karya gambar anak sangat ekspresi, karena pada umumnya pula gambar-gambar yang dihasilkan anak berupa gambar ekspresif yang di dalamnya menggambarkan keutamaan perasaan dan pikiran si penggambar. Oleh karena itu, gambar anak memiliki keunikan dan kekhasan yang dapat mencerminkan karakter yang ada di dalam diri anak. Apa yang digambarkan oleh anak merupakan hasil apa yang dilihat yang kemudian dirasakannya. Ekspresi anak saat menganggap dirinya sebagai pusat dunia, sampai mempunyai wawasan yang lebih luas, tercermin melalui gambar (Mubarok, 2008:49). Hal ini menandakan bahwa setiap goresan gambar membuka cakrawala berpikirnya, dan juga membebaskan jiwanya untuk berekspresi.

Namun fenomena yang terlihat dibeberapa sekolah, sejauh ini kegiatan menggambar dianggap kurang dimaknai dan dianggap kurang penting dalam kegiatan belajar anak. Guru terkadang memberikan kegiatan menggambar pada anak sebagai pengganti kegiatan pembelajaran lain atau sekedar mengisi waktu luang setelah anak selesai mengerjakan tugasnya. Akibatnya anak mengalami kesulitan dalam mengeluarkan ide dalam bentuk simbol gambar yang dikarenakan kurangnya pemberian stimulasi dari lingkungan sekitar anak. Simbol-simbol gambar tersebut sebenarnya akan mengiringi dan membawa anak dalam keterampilan menulisnya.

Selain itu, seringkali orang tua dan guru kurang memahami dan menyadari hasil karya gambar anak atau menganggap remeh coretan-coretan anak, sehingga pada akhirnya orang dewasa tidak menangkap pesan, gagasan, serta makna dari gambar yang telah dihasilkan oleh anak dan juga keterampilan yang terkandung dalam gambar anak, yaitu keterampilan menulisnya. Hal ini senada dengan yang diungkapan oleh Komalasari (2010:1) "Banyak orang yang melihat gambar anak hanya selintas lalu, melihat gambar anakanak hanya coretan-coretan tidak bermakna dengan bentuk-bentuk yang tidak sempurna". Oleh sebab itu, kemampuan yang semestinya dapat terlihat pada gambar anak menjadi tidak nampak yang dikarenakan tidak adanya analisis dan evaluasi terhadap perkembangan anak pada hasil gambarnya. Kegiatan menggambar padahal cukup sering dilakukan oleh anak baik di rumah maupun di sekolah.

Menggambar dan menulis merupakan kegiatan yang memiliki hubungan atau keterkaitan dalam mengembangkan kemampuan anak usia dini. Sebagaimana Steffani dan Paula (2009: 125) dalam penelitiannya mengungkapkan bahwa ada hubungan aktivitas menggambar, menulis, membaca dan matematika di TK. Hal lain juga diungkapkan oleh Clay (Yang, 2008:146) mengemukakan "children's drawing is closely linked to thinking, talking, reading and writing. They express and interpret meanings in mark making and drawings as well in speaking and writing". Gambar anak sangat berhubungan dengan aspek berpikir, berbicara, membaca dan menulis. Anak dapat mengekspresikan dan menggambarkan arti dari apa yang telah anak gambar sama halnya dengan berbicara dan menulis.

Dengan begitu, menggambar dan menulis merupakan proses perkembangan yang berjalan bersamaan sebagai cara anak mengekspresikan ide, pikiran, perasaan, dan pengalaman yang dituangkan anak melalui coretan gambar dan tulisan. Apa yang digambar atau ditulis oleh anak merupakan ekspresi dari dalam diri si anak. Walaupun yang digambar atau ditulis hanya berupa titik-titik maupun bulatan yang tidak terarah, namun mempunyai arti khusus untuk anak. Selain itu, tulisan-tulisan berupa simbol yang dituangkan dan dihasilkan anak dalam gambar merupakan bekal bagi keterampilan menulis dini. Berdasarkan uraian tersebut, maka penelitian ini akan mengkaji bagaimana kemunculan tahap menulis alfa- 
bet (alphabetic writing) pada gambar ekspresif anak usia 5-6 tahun di Pos PAUD, Kecamatan Kebayoran Lama, Jakarta Selatan.

Berdasarkan uraian di atas maka kajian teori dalam penelitian ini yaitu sebagai berikut:

\section{Tahap Alphabetic writing}

Menulis merupakan salah satu aspek keterampilan bahasa yang memiliki peranan penting di samping keterampilan berbahasa lainnya yang telah dikuasai, seperti menyimak, berbicara, dan membaca. Menulis dibutuhkan oleh anak untuk berkomunikasi dan menyampaikan pesan. Selain itu juga, sebagai penunjang untuk memahami pengetahuan yang sedang dipelajarinya, namun tetap membutuhkan latihan, bimbingan, dan motivasi dari lingkungan sekitar anak.

Secara umum Jalongo (2007:251-252) mengemukakan urutan perkembangan menulis yang sejalan dengan perkembangan seni anak, terutama yang berkaitan dengan menggambar dan telah digunakan untuk membahas perkembangan menulis secara lebih detail. Urutan perkembangan menulis tersebut yaitu: (1) Pre-alphabetic writing, (2) Random Scribbling, (3) Controlled Scribbling, (4) Naming Scribbling, (5) Alphabetic writing (6) Early Representational Drawing, Mock Letters, and Letters (7) Semiconventional Alphabetic writing, (8) Conventional Writing. Berdasarkan dari setiap tahapan perkembangan menulis tersebut mempunyai ciri dan peranannya masing-masing.

Tahap alphabetic writing menurut Jalongo di atas adalah tahap dimana tulisan anak menjadi lebih mudah dibaca. Dalam menulis, huruf-huruf dan angka-angka sering berkerumun seperti kata-kata, dan ukuran hurufnya pun tidak sesuai seperti umunya. Secara berangsur-angsur, anak mulai membuat koneksi atau menghubungkan antara huruf dan bunyi sebagai upaya untuk mencoba mengeja kata berdasarkan pada pemahamannya mengenai bahasa pada waktu yang sama saat itu. Meskipun pengejaan sementara dari kata tidak sesuai dengan ejaan yang ada di kamus atau ejaan yang berlaku. Tulisan yang dihasilkan anak, namun menjadi lebih mudah dibaca orang lain sebagai penambahan pengalaman anak.

Tahap menulis alfabet (alphabetic writing), menurut Schickedanz dan Schikedanz (2001:354) merupakan belajar untuk mengenali huruf-huruf pada alfabet. Adapun menurut Schickedanz dan Casbergue (2004:29) dalam buku yang berbeda mengungkapkan bahwa menulis alfabet pada anak prasekolah, yaitu dari rangkaian huruf ke kata-kata sebenarnya, nama anak-anak sebagai sumber pengetahuan untuk membuat kata, penggunaan huruf cetak lingkungan, dan awal ejaan fonemik. Hal ini menandakan bahwa dalam tahap alphabetic writing yang akan dilalui anak memiliki serangkaian proses tahapan yang mengalami perkembangan atau peningkatan dalam kemampuan menulisnya yang semakin lebih baik.

Pada anak usia 5-6 tahun, menurut Christopher (2004:1) ciri kemunculan menulis pada usia tersebut dijelaskan sebagai berikut; di masa ini ditandai dengan anak mulai melihat dirinya sebagai penulis. Beberapa anak mulai melabeli gambarnya dengan beberapa huruf. Anak dapat menulis namanya dan beberapa kata familiar dengan cara bahwa orang lain bisa membaca. Anak kadang-kadang hanya menuliskan huruf awal dan akhirnya saja berdasarkan dengan bunyi yang anak dengar. Pada masa ini, anak sering menulis semuanya dalam huruf-huruf besar. Anak mungkin berpura-pura untuk membaca tulisannya sendiri, sering menguraikan dengan ceritanya. Kemunculan menulis pada anak usia 5 tahun dijelaskan pula oleh Sacramento (2008:70) yaitu: "children demonstrate increasing emergent writing skills: adjust grasp and body position for increased control in drawing and writing, write letter or letter-like shapes to represent word or ide, write first name nearly correctly". Anak-anak menunjukkan peningkatan kemunculan keterampilan menulis; dengan mengatur pegangan dan posisi tubuh untuk meningkatkan kontrol dalam menggambar dan menulis, menulis huruf atau bentuk seperti huruf untuk mewakili kata atau ide, dan anak menulis namanya sendiri dengan atau tanpa kesalahan.

Munculnya keterampilan menulis tersebut, merupakan sikap positif terhadap menulis dan mencetak, pemahaman tentang konsep dan fungsi penulisan, representasi ide melalui coretan, gambar dan formasi huruf dasar, menyalin huruf cetak dari lingkungan, dan menghubungkan huruf kepada bunyi saat melakukan percobaan dengan menulis. Hal ini mengartikan dari banyaknya perspektif kemunculan keaksaraan (huruf), belajar untuk menulis dimulai sangat awal dalam sebuah kehidupan anak.

Dengan demikian, berdasarkan beberapa pendapat ahli mengenai tahap menulis alfabet (alphabetic writing) yang telah diuraikan, dapat dideskripsikan bahwa tahap menulis alfabet (alphabetic writing) adalah salah satu serangkaian tahap perkembangan menulis yang akan dilalui dan dialami anak seiring dengan bertambahnya usia. Tahap menulis alfabet (alphabetic writing) di sini, merupakan kegiatan awal anak dalam menulis huruf yang terdiri menulis nama panggilannya sendiri, menulis rangkaian huruf yang merepresentasikan sebuah kata, menulis dengan penggunaan ejaan awal fonemik, menulis kata, dan menulis kalimat atau bahkan menulis cerita. Tulisan 
yang dihasilkan anak kini dapat diidentifikasi sehingga lebih mudah dibaca atau dimengerti oleh orang lain.

\section{Gambar Ekspresif}

Menggambar merupakan sebuah aktivitas yang dapat menghasilkan suatu karya seni berupa gambar. Gambar memiliki berbagai macam jenis dan salah satunya adalah gambar ekspresif. Mubarak (2008:58) menjelaskan gambar ekspresif adalah jenis gambar yang mengungkapkan pikiran maupun perasaan anak terhadap sesuatu. Jenis gambar ini ditandai dengan pewarnaan yang sangat kaya. Objek-objeknya pun begitu nyata. Oleh karena itu, gambar ekspresif bukan hanya simbol-simbol yang digunakan untuk mengungkapkan dan mencurahkan ungkapan batin atau perasaan, tetapi juga dapat digunakan sebagai ungkapan maksud, gagasan, yang ingin disampaikan oleh pembuatnya kepada orang lain dalam bentuk yang dapat dirasakan oleh indera.

Gambar ekspresif biasanya digambar secara bebas berdasarkan pada imajinasi, persepsi, dan penafsiran penggambar kepada objeknya. Dalam karya gambar ekspresif mengabaikan kemiripan akan objek yang digambar, tetapi lebih mengutamakan perasaan, keinginan pribadi penggambar yang tidak mustahil menghasilkan gambar yang kreatif sesuai dengan keinginannya. Menurut Handayani dan Murtono (2009:83), gambar ekspresif yaitu gambar bebas yang dapat diartikan sebagai gambar yang mengungkapkan perasaan pembuatnya. Gambar ekspresif tidak boleh meniru gambar orang lain. Gambar ekspresif bukan hanya sebagai gambar yang mengandung ungkapan perasaan pembuatnnya saja, namun memiliki ketentuan dalam pembuatannya yaitu dalam membuatnya tidak boleh meniru dari gambar orang lain, jadi merupakan hasil karya gambar sendiri.

Berdasarkan definisi di atas, dapat dideskripsikan bahwa gambar ekspresif adalah sebuah hasil karya seni berupa gambar yang di dalamnya lebih mengutamakan ungkapan perasaan, pikiran, serta keinginan pribadi penggambar/pembuatnya. Di dalam gambar ekspresif, biasanya dicerminkan dengan pewarnaan yang kaya dan objek yang nyata sehingga dapat dirasakan oleh indera.

\section{METODELOGI PENELITIAN}

Metode yang digunakan dalam penelitian ini adalah deskriptif dengan pendekatan survei. Penelitian survei, menurut Cohen dan Nomion (Sukardi, 2008:193) menjelaskan sebagai berikut: "Survey gathers data at a particular point in the time". Artinya penelitian survei merupakan kegiatan penelitian yang mengumpulkan data pada saat tertentu. Penelitian ini dilaksanakan pada bulan Oktober 2013 di Pos PAUD nonformal yang berada di wilayah Kecamatan Kebayoran Lama, Jakarta Selatan. Penelitian ini dilaksanakan pada bulan Oktober 2013. Data dan Sumber informasi utama dalam penelitian ini, yaitu anak usia 5-6 tahun yang mengikuti pendidikan di Pos PAUD (BKB Rw) yang berada di wilayah Kecamatan Kebayoran Lama Jakarta Selatan dengan jumlah 52 Pos PAUD. Pos PAUD yang didapatkan untuk dijadikan sebagai sampel peneltian dilakukan dengan teknik cluster random sampling. Adapun 6 Pos PAUD di wilayah Kecamatan Kebayoran Lama Jakarta Selatan, yaitu BKB PAUD Kemuning Grogol Selatan, BKB PAUD Cempaka Grogol Utara, BKB PAUD Seruni Ceria Kebayoran Lama Selatan, BKB PAUD Permata Bunda Kebayoran Lama Utara, BKB PAUD Buncis Pondok Pinang, dan BKB PAUD Flamboyan Cipulir. Kemudian dari masing-masing Pos PAUD, sampel (anak) yang didapatkan kemudian diklasifikasikan atau dikelompokkan berdasarkan usia anak, yaitu dari usia 5 tahun 0 bulan sampai dengan usia 6 tahun dengan 4 Jurnal IImiah VISI P2TK PAUD NI - Vol. 9, No.1, Juni 2014 jumlah sampel keseluruhan adalah 75 anak. Adapun sebaran jumlah anak dalam setiap kelompok usianya akan diuraikan dalam tabel berikut ini:

Tabel 1. Sebaran Jumlah Anak

\begin{tabular}{|c|c|c|}
\hline No. & Usia & Jumlah Anak \\
\hline 1. & 5 Tahun 0 Bulan & 5 Anak \\
\hline 2. & 5 Tahun 1 Bulan & 5 Anak \\
\hline 3. & 5 Tahun 2 Bulan & 6 Anak \\
\hline 4. & 5 Tahun 3 Bulan & 6 Anak \\
\hline 5. & 5 Tahun 4 Bulan & 6 Anak \\
\hline 6. & 5 Tahun 5 Bulan & 6 Anak \\
\hline 7. & 5 Tahun 6 Bulan & 5 Anak \\
\hline 8. & 5 Tahun 7 Bulan & 6 Anak \\
\hline 9. & 5 Tahun 8 Bulan & 6 Anak \\
\hline 10. & 5 Tahun 9 Bulan & 6 Anak \\
\hline 11. & 5 Tahun 10 Bulan & 6 Anak \\
\hline 12. & 5 Tahun 11 Bulan & 6 Anak \\
\hline 13. & 6 Tahun & 6 Anak \\
\hline \multicolumn{2}{|r|}{ Jumlah } & 75 Anak \\
\hline
\end{tabular}

Kisi-kisi instrumen kemunculan tahap menulis alfabet (alphabetic writing) pada gambar ekspresif anak usia 5-6 tahun adalah sebagai berikut: 1) Menulis huruf yang mencakup terdapatnya coretan huruf minimal 1 huruf, coretan huruf yang sama secara berulang, dan deretan huruf seperti kata-kata. 2) Menulis nama sendiri yang mencakup terdapatnya tulisan berupa 
nama panggilan anak pada hasil karya gambar yang dibuat. 3) Menulis rangkaian huruf yang merepesentasikan sebuah kata yang mencakup terdapatnya coretan huruf yang sama dengan bagian huruf dari namanya dan terdapatnya coretan yang dibuat anak yang merupakan representasi dari sebuah kata. 4) Menulis berdasarkan fonem (bunyi huruf) yang mencakup terdapatnya tulisan dengan bunyi yang benar pada huruf pertama dalam sebuah kata, terdapatnya tulisan yang menggunakan bentuk tulisan dengan bunyinya secara bersamaan, dan terdapatnya tulisan dengan akhiran bunyi seperti "ng dan ny". 5) Menulis kata yang mencakup terdapatnya salah satu huruf dari sebuah kata, terdapatnya 2-3 huruf dari rangkaian kata, susunan huruf yang lengkap dan benar, dan terdapatnya label kata berupa nama benda yang berhubungan dengan gambarnya. 6) Menulis kalimat pendek sesuai ejaan yang mencakup terdapatnya kalimat pendek yang terdiri dari 2-3 kata serta penggunaan spasi antar kata dalam kalimat. 7) Menulis sendiri cerita sesuai dengan gambar yang dibuat yang mencakup terdapatnya cerita yang dibuat sendiri dengan susunan kata yang lengkap, hurufnya benar, dan menggunakan spasi sesuai dengan gambar yang dibuat.

Uji validitas instrumen penelitian ini menggunakan expert judgement dari tiga orang ahli dibidang bahasa dan pendidikan yang benar-benar paham tentang indikator yang hendak diamati, yaitu Dra.
Nurbiana Dhieni, M.Psi, Ade Dwi Utami, S.Pd.,M. Pd, dan Dra. Gusti Yarmi, M.Pd. Adapun reliabilitas menggunakan perhitungan rumus Anova Hoyt yang menghasilkan perhitungan sebesar 0,983 . Perhitungan tersebut masuk ke dalam kategori $(0,90-1,00)$, maka dengan demikian instrumen ini memiliki reliabilitas "Sangat Tinggi". Dengan kata lain kedua penilai (rater) memberikan penilaian objektif yang tinggi dan hampir sama terhadap kemunculan tahap alphabetic writing pada gambar ekspresif anak usia 5-6 tahun, yaitu:

Tabel 2. Penilaian Tahap Alphabetic Writing

\begin{tabular}{|l|l|l|l|}
\hline Varians & JK & db & RJK \\
\hline Total & 2690.7 & 29 & - \\
\hline Antar Penilai (Rater) & 16.2 & 1 & - \\
\hline Antar Subjek & 2630.7 & 14 & 187.90 \\
\hline Sisa (Residu) & 43.8 & 14 & 3.12 \\
\hline
\end{tabular}

Untuk pengumpulan data, peneliti menggunakan instrumen dalam melakukan penilaian kemunculan tahap menulis alfabet (alphabetic writing) pada gambar ekspresif anak usia 5-6 tahun. Selain itu, untuk melengkapi data kemunculan tahap menulis alfabet (alphabetic writing) pada gambar ekspresif anak usia 5-6 tahun dilakukan dengan teknik wawancara terstruktur. Teknik analisis data penelitian diolah dengan menggunakan teknik persentase.

\section{HASIL DAN PEMBAHASAN}

Hasil penelitian dari penilaian data kemunculan tahap alphabetic writing pada gambar ekspresif yang diperoleh dari 75 anak dari masing-masing tahapan dengan rentang atau tingkatan usia yaitu dari usia 5 tahun 0 bulan sampai dengan usia 6 tahun, disajikan dengan penghitungan menggunakan prosentase yang akan digambarkan melalui tabel 1 sebagai berikut:

Tabel 3. Tahap Alphabetic Writing pada Gambar Ekspresif

\begin{tabular}{|c|c|c|c|c|c|c|c|c|}
\hline \multirow{2}{*}{ No } & \multirow{2}{*}{ Usia } & \multicolumn{7}{|c|}{ Indikator Rata-rata } \\
\cline { 3 - 9 } & $\begin{array}{c}\text { Menulis } \\
\text { Huruf }\end{array}$ & $\begin{array}{c}\text { Menulis } \\
\text { Nama } \\
\text { Sendiri }\end{array}$ & $\begin{array}{c}\text { Menulis } \\
\text { Rang- } \\
\text { kaian } \\
\text { Huruf }\end{array}$ & $\begin{array}{c}\text { Menulis } \\
\text { Fonem }\end{array}$ & $\begin{array}{c}\text { Menulis } \\
\text { Kata }\end{array}$ & $\begin{array}{c}\text { Menulis } \\
\text { Kalimat } \\
\text { Pendek }\end{array}$ & $\begin{array}{c}\text { Menulis } \\
\text { Sendiri } \\
\text { Cerita }\end{array}$ \\
\hline 1 & 5 Tahun & $40 \%$ & $20 \%$ & $0 \%$ & $0 \%$ & $0 \%$ & $0 \%$ & $0 \%$ \\
\hline 2 & 5,1 Bulan & $60 \%$ & $60 \%$ & $20 \%$ & $20 \%$ & $20 \%$ & $0 \%$ & $0 \%$ \\
\hline 3 & 5,2 Bulan & $67 \%$ & $83 \%$ & $67 \%$ & $50 \%$ & $33 \%$ & $0 \%$ & $0 \%$ \\
\hline 4 & 5,3 Bulan & $67 \%$ & $67 \%$ & $33 \%$ & $50 \%$ & $33 \%$ & $0 \%$ & $0 \%$ \\
\hline 5 & 5,4 Bulan & $67 \%$ & $83 \%$ & $50 \%$ & $67 \%$ & $50 \%$ & $0 \%$ & $0 \%$ \\
\hline 6 & 5,5 Bulan & $83 \%$ & $67 \%$ & $67 \%$ & $67 \%$ & $67 \%$ & $0 \%$ & $0 \%$ \\
\hline 7 & 5,6 Bulan & $80 \%$ & $80 \%$ & $80 \%$ & $80 \%$ & $60 \%$ & $0 \%$ & $0 \%$ \\
\hline 8 & 5,7 Bulan & $83 \%$ & $67 \%$ & $83 \%$ & $83 \%$ & $83 \%$ & $17 \%$ & $0 \%$ \\
\hline 9 & 5,8 Bulan & $83 \%$ & $67 \%$ & $67 \%$ & $67 \%$ & $67 \%$ & $0 \%$ & $0 \%$ \\
\hline 10 & 5,9 Bulan & $100 \%$ & $100 \%$ & $100 \%$ & $100 \%$ & $100 \%$ & $50 \%$ & $0 \%$ \\
\hline
\end{tabular}




\begin{tabular}{|c|c|c|c|c|c|c|c|c|}
\hline \multirow{2}{*}{ No } & Usia & $\begin{array}{c}\text { Menulis } \\
\text { Huruf }\end{array}$ & $\begin{array}{c}\text { Menulis } \\
\text { Nama } \\
\text { Sendiri }\end{array}$ & $\begin{array}{c}\text { Menulis } \\
\text { Rang- } \\
\text { kaian } \\
\text { Huruf }\end{array}$ & $\begin{array}{c}\text { Menulis } \\
\text { Fonem }\end{array}$ & $\begin{array}{c}\text { Menulis } \\
\text { Kata }\end{array}$ & $\begin{array}{c}\text { Menulis } \\
\text { Kalimat } \\
\text { Pendek }\end{array}$ & $\begin{array}{c}\text { Menulis } \\
\text { Sendiri } \\
\text { Cerita }\end{array}$ \\
\hline 11 & 5,10 Bulan & $100 \%$ & $100 \%$ & $100 \%$ & $100 \%$ & $100 \%$ & $17 \%$ & $17 \%$ \\
\hline 12 & 5,11 Bulan & $100 \%$ & $100 \%$ & $100 \%$ & $100 \%$ & $100 \%$ & $50 \%$ & $17 \%$ \\
\hline 13 & 6 Tahun & $100 \%$ & $100 \%$ & $100 \%$ & $100 \%$ & $100 \%$ & $67 \%$ & $50 \%$ \\
\hline
\end{tabular}

Berdasarkan hasil analisa dan interpretasi dari hasil rekapitulasi data mengenai kemunculan tahap alphabetic writing pada gambar ekspresif anak usia 5-6 tahun, dalam tabel di atas yang telah diuraikan berdasarkan tahapan usianya yaitu usia 5 tahun 0 bulan sampai dengan 6 tahun, menunjukkan bahwa data tersebut membuktikan bahwa pada hasil gambar ekspresif anak dapat mengidentifikasi kemampuan tahap perkembangan menulis anak. Selain itu, dapat terlihat adanya perbedaan yang ditunjukkan dengan hasil persentase yang didapatkan dari masing-masing tahapan rata-rata kemunculannya memiliki jumlah dalam kriteria "muncul" yang berbeda-beda yang mengalami peningkatan yang semakin lebih baik. Selain itu, dapat dilihat pada gambar ekspresif yang telah dihasilkan anak usia 5-6 tahun atau yang dikelompokkan dari usia 5 tahun 0 bulan sampai 6 tahun dalam gambar 1 berikut ini:

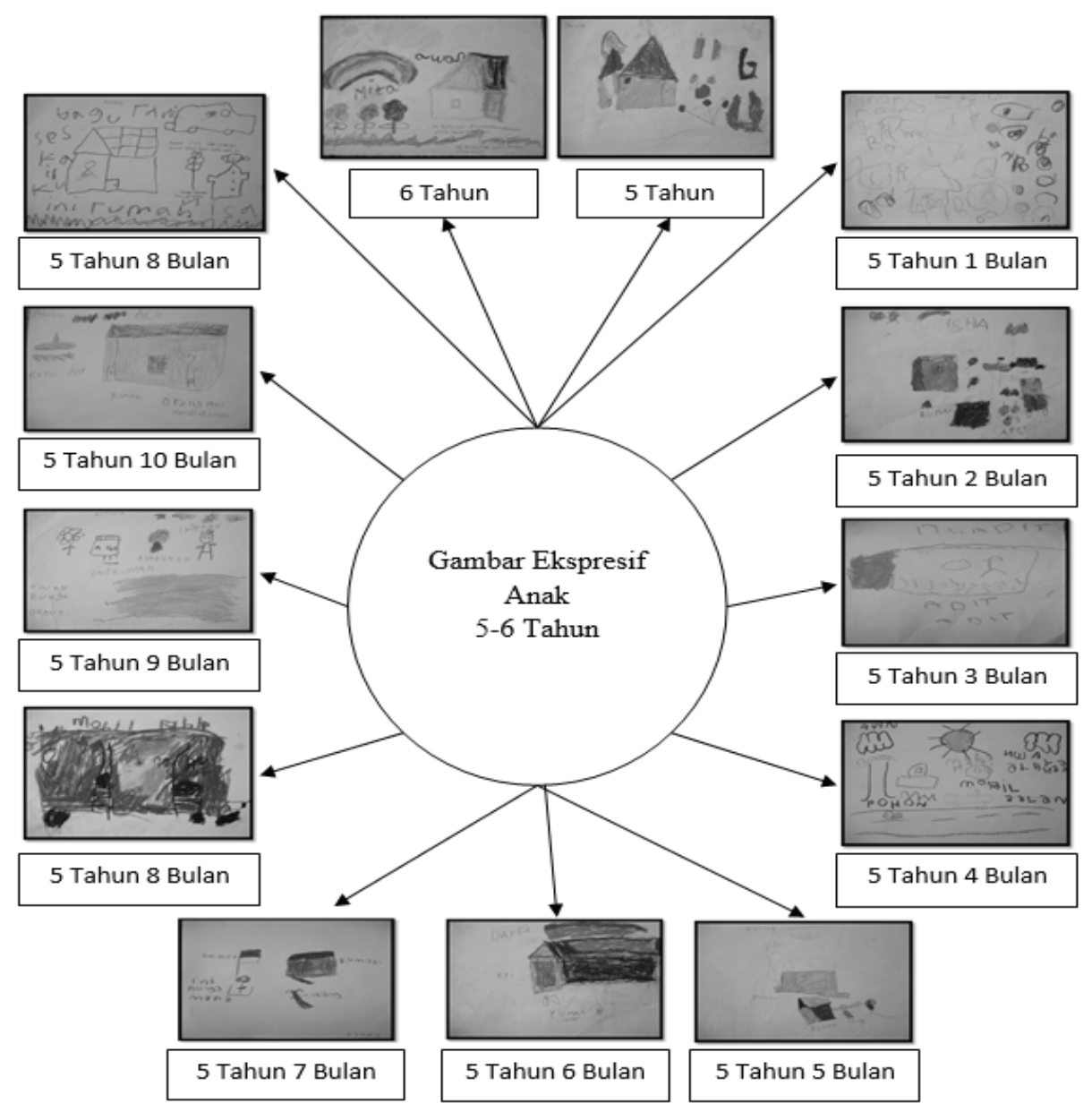

Gambar 1. Hasil gambar ekspresif anak usia 5 Tahun 0 bulan sampai dengan 6 tahun

Kemunculan tahap alphabetic writing pada gambar ekspresif anak usia 5-6 tahun dapat dideskripsikan antara lain, yaitu pada tahap menulis huruf, kemunculannya sudah terdapat sejak anak di usia 5 tahun 0 bulan, yaitu persentase yang dihasilkan sebesar $40 \%$. Kemunculan tahap menulis huruf ini, muncul semakin meningkat lebih baik hingga anak usia 6 tahun dengan persentase yang dihasilkan sebesar $100 \%$. Dalam ta- 
hap ini, anak menuliskan huruf hanya sebagai ekspresi dirinya atau ide yang dituangkan dalam coretan huruf. Pernyataan tersebut sesuai pendapat Sacramento menjelaskan "write letter or letter-like shapes to represent word or ide". Ungkapan tersebut diartikan bahwa anak menulis huruf atau bentuk seperti huruf untuk mewakili kata atau ide. Hal ini dikarenakan huruf yang muncul tersebut tidak memiliki makna yang berkaitan dengan gambarnya atau masih banyak yang ditemukan hanya berupa hasil gambar saja. Biasanya bentuk hurufnya terbalik atau belum serupa dengan bentuk huruf aslinya. Selain itu, dari beberapa wawancara yang dilakukan kebanyakan anak menjawab "Gak tau" sehingga peneliti tidak mendapatkan informasi apapun. Dengan demikian, pada tahap ini, namun dapat dideskripsikan bahwa hampir keseluruhan anak usia 5-6 tahun dalam hasil gambar ekspresifnya sudah terdapat muncul coretan huruf dengan bentuk huruf sebenarnya.

Pada tahap menulis nama sendiri, kemunculannyapun sudah terdapat sejak anak di usia 5 tahun 0 bulan dengan hasil persentase sebesar $20 \%$. Kemunculan tahap menulis nama sendiri semakin meningkat dengan persentase yang dihasilkan hingga 100\% yang dimulai dari anak usia 5 tahun 9 bulan sampai dengan 6 tahun. Anak menuliskan namanya sendiri sesuai dengan ejaan huruf-huruf dalam namanya, walapun bentuk hurufnya, masih terdapat ada yang terbalik. Hal ini sesuai dengan pendapat Sacramento dijelaskan mengenai kemunculan menulis pada anak usia 5 tahun, yaitu salah satunya adalah menulis nama sendiri pertama hampir benar. Anak menulis namanya sendiri dengan atau tanpa kesalahan, seperti memasuki beberapa huruf, membalikan beberapa huruf, atau menggunakan huruf yang mungkin tidak ditulis dalam satu baris. Lain halnya, namun masih ditemukan beberapa anak belum menuliskan namanya sendiri sehingga yang terdapat berupa hasil gambar saja. Hal ini diperkuat pula dengan hasil wawancara, bahwa anak memang tidak ingin menuliskan namanya sendiri karena tidak tertarik atau karena lupa. Namun demikian, dapat dideskripsikan bahwa hampir keseluruhan anak usia 5-6 tahun pun sudah mampu menuliskan nama panggilannya sendiri dengan benar.

Pada tahapan menulis rangkaian huruf yang merepresentasikan sebuah kata pada gambarnya, terdapat muncul di usia anak 5 tahun 1 bulan dengan hasil persentase sebesar $20 \%$. Kemunculan pada tahap ini pun terlihat terus mengalami peningkatan hingga anak usia 6 tahun. Hasil persentase yang diperoleh sebesar $100 \%$. Kemunculan pada tahap ini, dapat dideskripsikan bahwa pada anak usia 5-6 tahun terdapatnya rangkaian huruf yang muncul sudah dengan jelas. Tulisan berupa deretan huruf-huruf tersebut mulai memiliki makna yang berkaitan dengan gambarnya, walaupun terkadang anak mengalami kebingungan untuk mengartikan atau memaknai tulisannya. Hal ini dikarenakan kemungkinan anak merasa malu ketika diwawancara, sehingga anak memerlukan bantuan untuk mengungkapkan maksud dari rangkaian tulisannya tersebut. Selain itu, biasanya kesalahan pada tahap ini, anak mengalami kesulitan untuk menemukan rangkaian huruf dalam menuliskan kata yang dimaksudkannya.

Pada tahap menulis berdasarkan fonem (bunyi huruf) atau menulis fonemik, kemunculannyapun muncul di usia anak 5 tahun 1 bulan dengan persentase yang dihasilkan sebesar $20 \%$. Kemunculan pada tahap ini persentase yang dihasilkan baru benar-benar sempurna atau konsisten di usia anak 5 tahun 9 bulan sampai dengan usia 6 tahun, yaitu dengan persentase yang diperoleh sebesar $100 \%$. Pada tahap ini, anak menulis dengan menggunakan bentuk tulisan dan bunyinya secara bersamaan. Tulisan anak didasarkan pada bunyinya. Hal ini sesuai dengan pendapat Schickedanz bahwa tahap menulis alfabet pada anak prasekolah salah satunya yaitu ejaan awal fonemik. Anak membuat koneksi atau hubungan antara bunyi dan huruf untuk mewakili bunyi dalam menulis sebuah kata. Namun demikian, keterampilan mengoperasikan prinsip fonetik atau kesadaran fonemiknya (bunyi huruf) masih sangat terbatas. Akibatnya anak seringkali menggunakan dua sampai tiga huruf saja dalam membentuk atau menuliskan sebuah kata

Pada tahap menulis kata, kemunculannya sama dengan tahapan sebelumnya ditemukan di usia anak 5 tahun 1 bulan dengan hasil persentase yang diperoleh sebesar $20 \%$. Pada tahap ini kemunculannya semakin lebih baik dengan persentase yang dihasilkan terus mengalami peningkatan hingga mencapai $100 \%$ sejak usia 5 tahun 9 bulan sampai dengan 6 tahun. Terdapatnya muncul tulisan kata tersebut sebagai label kata berupa nama benda yang berhubungan dengan gambarnya. Seperti yang diungkapkan oleh Christoper, bahwa ciri kemunculan menulis pada anak dimasa ini ditandai dengan anak mulai melihat dirinya sebagai penulis. Beberapa anak mulai melabeli gambarnya dengan beberapa huruf, walaupun kadang-kadang anak hanya menuliskan huruf awal dan akhirnya saja. Pada masa ini, anak sering menulis semuanya dalam huruf-huruf besar. Anak yang menuliskan kata (label kata) pada gambarnya, dikarenakan adanya pembiasaan dan latihan untuk memberikan judul pada gambar yang telah dibuatnya, walaupun terkadang su- 
sunan atau rangkaian hurufnya masih ada yang kurang atau belum lengkap karena berdasarkan kemampuan anak sendiri. Tulisan anak biasanya menggunakan huruf besar dan huruf kecil secara bercampur atau menggunkan semua hurufnya besar atau huruf kecil.

Dengan begitu, namun masih ditemukan beberapa anak belum terdapat tulisan apapun pada gambar ekspresifnya. Hal ini diperkuat dengan hasil wawancara, bahwa anak memang tidak ingin menuliskan apapun pada gambarnya karena anak memang tidak tertarik. Di samping itu, kesalahan yang umum terjadi pada anak dalam menulis kata yaitu biasanya anak mengalami kesulitan pada kata yang memiliki akhiran "ng". Anak menuliskannya ada salah satu huruf yang tertinggal atau posisinya terbalik, apakah itu huruf " $n$ " atau "g" nya. Namun demikian, dapat dideskripsikan bahwa hampir keseluruhan anak usia 5-6 tahun pun sudah dapat memiliki kemampuan dalam menulis kata dengan rangkaian dan susunan huruf yang lengkap dan benar.

Pada penelitian ini pula, ditemukan beberapa anak usia 5-6 tahun dalam gambar ekspresifnya terdapat muncul tulisan kalimat pendek. Kemunculan pada tahap menulis kalimat pendek, baru terdapat di usia anak 5 tahun 7 bulan. Persentase yang diperoleh hanya sebesar $17 \%$ dan meningkat sampai $67 \%$ di usia 6 tahun. Pada tahap ini, biasanya anak menuliskan kalimat yang terdiri dari 2-3 kata pendek yang disusun dan dirangkai menjadi sebuah kalimat sederhana. Tulisan kalimat tersebut biasanya diawali dengan kata "ini" yang kemudian diikuti dengan kata bendanya. Pada penulisan kalimat, kesalahan yang terjadi biasanya anak mengalami kesulitan dalam menuliskan kata bendanya yaitu rangkaian hurufnya terdapat masih belum lengkap dan benar.

Adapun pada tahap menulis sendiri cerita sesuai dengan gambar yang dibuat, baru ditemukan muncul di usia 5 tahun 10 bulan dan hasil persentase yang dihasilkan pun hanya sebesar 17\%. Dalam tahapan ini, anak menuliskan sendiri cerita yang mendeskripsikan gambarnya. Anak dapat menulis dengan benar sebagian besar kata dengan memisahkan kata satu dengan kata yang lain. Anak sudah mampu menuliskan kata dan kalimat, meskipun belum konsisten. Anak sudah dapat menggunakan ejaan dan tanda baca dalam menulis, khususnya pemberian jarak atau spasi antar kata. Hal ini sesuai dengan penjelasan Sckhicdezan, secara berangsur-angsur anak belajar cetak konvensional yaitu bagaimana kata-kata diakui pada halaman atau kata sesuai dengan ejaan yang berlaku. Anak mulai memperhatikan awal letak penulisan yang dimulai dari kiri ke kanan, dari kanan ke kiri atau digunakan keduanya.

Berdasarkan uraian tersebut dapat dideskripsikan bahwa dari beberapa anak usia 5-6 tahun dalam penelitian ini, ditemukan sudah dapat menulis kalimat pendek dan cerita sendiri yang walapun belum secara sempurna dalam penulisan kata-kata. Hal ini dikarenakan seringnya anak diberikan stimulasi atau rangsangan dengan memberikan kesempatan seluasluasnya untuk menungkan ide imajinatifnya dalam bentuk tulisan. Dari hasil wawancara yang dilakukan, memang anak suka menulis baik di atas kertas maupun dinding rumahnya.

Dengan demikian, pada hasil gambar ekspresif anak usia 5-6 tahun dalam penelitian yang telah dilakukan ternyata dapat mengidentifikasi kemampuan menulis anak yang berada pada tahapannya masingmasing dengan kemunculan kemampuan menulisnya yang berbeda-beda pula. Hal ini dikarenakan kegiatan menggambar merupakan kegiatan yang sangat disukai dan menyenangkan bagi anak sejak dini. Menggambar sebagai sarana bagi anak untuk dapat mengoptimalkan berbagai kemampuan yang dimiliki anak. Anak dapat mengungkapkan dan mengekspresikan berbagai ide, pikiran, perasaan dan pengalamannya masing-masing dalam bentuk gambar dan tulisan. Hal ini sebagaimana Sudono mengemukakan kegiatan menggambar yang dilakukan anak memiliki tujuan dalam mengembangkan kemampuan berbahasa. Kemampuan berbahasa dalam penelitian ini salah satunya adalah kemampuan menulis alfabet (alphabetic writing) yang tulisan dihasilkannya dapat diidentifikasi sehingga lebih mudah dibaca dan dimengerti maksudnya. Pernyataan ini sesuai dengan Jalongo yang mengungkapkan tahap alphabetic writing adalah tahap dimana tulisan anak menjadi lebih mudah dibaca.

Hal terpenting dalam mengembangkan kemunculan tahap alphabetic writing pada gambar ekspresif anak adalah adanya pemberian stimulasi serta kesempatan dengan memberikan kebebasan pada anak dalam megekspresikan ide, perasaan dan penglamannya. Selain itu, perlu adanya pemberian fasilitas berupa penyediaan alat dan bahan yang mendukung dalam kegiatan menggambar, agar anak dapat menuangkan pikiran dan perasaannya baik itu dalam bentuk gambar maupun tulisan. Di samping itu, orang dewasa tidak perlu selalu meremehkan hasil gambar anak yang hanya terlihat berupa coretan yang tidak bermakna, namun sebaliknya orang dewasa dapat menganalisis dari kegiatan menulis (alphabetic writing) terhadap apa yang telah dibuatnya yang terdapat pada hasil gambar ekspresif anak. Selain itu juga, orang dewasa tidak perlu terlalu mengoreksi tulisan yang belum di- 
mengerti anak tetapi lebih baik memberikan fasilitas berupa pajangan tempelan tulisan-tulisan yang dapat memperbaiki ejaan tulisannya kelak.

\section{PENUTUP}

\section{Kesimpulan}

Berdasarkan hasil perhitungan sebelumnya, terlihat bahwa kemunculan tahap alphabetic writing pada gambar ekspresif anak usia 5-6 tahun memiliki perbedaan dalam kemunculan menulisnya pada setiap tahapan. Pada tahap menulis huruf dan menulis nama sendiri terdapat muncul sejak anak di usia 5 tahun 0 bulan sampai dengan 6 tahun. Adapun dalam tahap menulis rangkaian huruf yang merepresentasikan sebuah kata, menulis berdasarkan fonem (bunyi huruf), dan menulis kata taerdapat muncul di usia anak 5 tahun 1 bulan sampai dengan 6 tahun. Hal lainnya yang ditemukan juga, pada anak usia 5-6 tahun yang dimulai dari usia 5 tahun 7 bulan sampai dengan usia 6 tahun terdapat sudah mampu dalam menulis kalimat pendek sesuai ejaan, sedangkan dalam menulis sendiri cerita sesuai dengan gambar yang dibuat, muncul pada usia 5 tahun 10 bulan sampai usia 6 tahun walaupun hanya muncul pada beberapa anak saja. Dengan demikian, maka dapat ditarik kesimpulan bahwa dari hasil gambar ekspresif anak dengan semakin bertambahnya usia, kemunculan tahap perkembangan menulis anak semakin lebih baik. Hal ini ditunjukkan dengan usia 5 tahun 0 bulan sampai dengan usia 6 tahun berada pada tahapan perkembangan menulis dan kemunculan yang dihasilkannya berbeda-beda yang berkembang sesuai tahapannya. Oleh karena itu, tetap perlu adanya pemberian stimulasi dari lingkungan sekitar anak agar anak dapat mengembangkan kemunculan dalam kemampuan menulisnya di tahap alphabetic writing menjadi lebih baik lagi.

\section{DAFTAR PUSTAKA}

Christopher. (2003). Development continums. New York: Gordon Publishers.

Handayani, Tri dan Sri Murtono. (2009). Seni budaya dan Keterampilan 1 untuk Kelas 1 SD. Jakarta: Quadra.

Jalongo, Mary Renck. (2007). Early childhood language arts fourth edition. New York: Pearson Education.

Mubarok, M. Mufti. (2008). Rahasia cerdas belajar sambil bermain. Surabaya: PT. Java Pustaka.

Sacramento. (2008). California preschool learning foundations Volume 1. California Department of Education.

Schickedanz, Judith A, David I. Schickedanz, et.al,. (2001). Understanding children and adolescents fourth edition. Boston: Allyn and Bacon.

Schickedanz, Judith A and Renee M. Casbergue. (2005). Writing preschool learning to orches- trate meaning and marks second printing. USA: International Reading Association.

Steffani, Sussan and Paula M. Selvester. (2009). The relationship of drawing, writting, literacy and math in kindergarten children Volume 49 (2) (Proquest Education Journals).

Sukardi. (2008). Metodologi penelitian pendidikan kompetensi dan praktiknya. Jakarta: PT. Bumi Aksara.

Yang, Hui-Chin and Andrea M.Noel. (2008). "The developmental characteristics of four-and fiveyear-old preschoolers drawing: an analysis of scribbles, palcement patterns, emergent writing, and name writing in archived spontaneous drawing samples volume 6 (2)" (Journal of Early Childhood Literacy). 